Pacific Journal of Mathematic 


\title{
ON EXTENSION OF ROTUND NORMS II
}

\author{
K. JOHN AND V. ZiZLER
}

It is proved that if $X$ is a Banach space, $Y \subset X$ with $X / Y$ separable and $\|\cdot\|$ is an equivalent locally uniformly rotund norm on $Y$, then $\mid[\cdot \|$ can be extended to such a norm on $X$.

This generalizes [2] where it was shown that any locally uniformly rotund equivalent norm on a closed subspace of a separable Banach space $X$ can be extended to such a norm on $X$.

By a subspace we mean a closed linear subspace, $\mathrm{sp} L$ denotes the linear hull of $L$ and $x \rightarrow \widehat{x}$ stands for the quotient map $X \rightarrow X / Y$ if $Y$ is a subspace of $X$.

Let us recall that a norm $\|\cdot\|$ on a Banach space $X$ is locally uniformly rotund (LUR) if whenever $\lim 2\left(\|x\|^{2}+\left\|x_{j}\right\|^{2}\right)-\left\|x+x_{j}\right\|^{2}=$ $0, x, x_{j} \in X$, then $\lim \left\|x-x_{j}\right\|=0$. $\|\cdot\|$ is rotund $(R)$ if for any $x, y \in X, x \neq y, 2\left(\|x\|^{2}+\|y\|^{2}\right)-\|x+y\|^{2}>0$.

THeOREM 1. Let $X$ be a Banach space, $Y \subset X$ a subspace of $X$. Suppose $X / Y$ is separable and $Y$ admits an equivalent norm $\|\cdot\|$ which is LUR $(R)$. Then $\|\cdot\|$ can be extended to an equivalent norm $\|\cdot\|$ on $X$ which is $\operatorname{LUR}(R)$.

\section{Proof. Let us start with the case of LUR.}

First extend the given LUR norm $\|\cdot\|$ on $Y$ to an equivalent norm $\|\cdot\|$ on $X$ : This can easily be done as follows: Take the closed unit ball $B_{1}^{Y}$ of $Y$ with respect to $\|\cdot\|$ and the closed ball $B$ of $X$ such that $B \cap Y \subset B_{1}^{Y}$. Then, easily, the Minkowski functional of conv $\left(B \cup B_{1}^{Y}\right)$ is the desired norm on $X$ (cf. e.g., [4], [2]).

Furthermore, let $\left\{\hat{a}_{n}\right\}_{n=1}^{\infty} \subset X / Y, \widehat{a}_{n} \neq 0$ be a dense subset of $X / Y$. Let $S: X / Y \rightarrow X$ denote the Bartle-Graves continuous selection map $(S \hat{x} \in \hat{x})$ and $a_{n}=S \hat{a}_{n}$.

For $n \in N$ ( $N$ positive integers), choose $f_{n} \in X^{*}, f_{n}\left(a_{n}\right)=1,\left\|f_{n}\right\|=$ $\left\|\hat{a}_{n}\right\|^{-1}, f_{n}=0$ on $Y$ and denote by $P_{n}(x)=f_{n}(x) a_{n}, P_{n}^{\prime}=I-P_{n}$ where $I$ is the identity map on $X$.

Consider

$$
\|\| x\left\|^{2}=(1-c)\right\| x\left\|^{2}+\sum_{n=1}^{\infty} 2^{-n}\left(1+\left\|P_{n}\right\|\right)^{-2} \cdot\right\| x-P_{n} x\left\|^{2}+\right\| \hat{x} \|^{2},
$$

where $c=\sum_{n=1}^{\infty}\left(1+\left\|P_{n}\right\|\right)^{-2} 2^{-n},\|\hat{\bullet}\|$ is an equivalent LUR norm on $X / Y([3])$.

Then (i) $\|\cdot \mid\|$ is an equivalent norm on $X$ which agree with $\|\cdot\|$ 
on $Y$,

(ii) $\|\cdot \cdot\| \|$ is LUR.

(i) is easily seen.

To see (ii), assume there is an $\varepsilon>0$ such that

$$
\lim 2\left(\left.\left|\left\|x||^{2}+\left.\left|\| x_{m}\right|\right|^{2}\right)-\|\| x+x_{m}\right|\right|^{2}=0\right.
$$

and

$$
\|\left|x-x_{m}\right|||>\varepsilon
$$

and find a contradiction.

From (1),

$$
\lim 2\left(\|\hat{x}\|^{2}+\left\|\hat{x}_{m}\right\|^{2}\right)-\left\|\hat{x}+\hat{x}_{m}\right\|^{2}=0,
$$

(4) $\lim _{m} 2\left(\left\|P_{n}^{\prime} x\right\|^{2}+\left\|P_{n}^{\prime} x_{m}\right\|^{2}\right)-\left\|P_{n}^{\prime}\left(x+x_{m}\right)\right\|^{2}=0, \quad$ for $n \in N$

$$
\begin{gathered}
\lim 2\left(\|x\|^{2}+\left\|x_{m}\right\|^{2}\right)-\left\|x+x_{m}\right\|^{2}=0, \\
K=\max \left(\sup \left\|x_{n}\right\|, 1\right)<\infty .
\end{gathered}
$$

If $x \in Y$, then $\hat{x}=0$ and form $(3), \lim \left\|\hat{x}_{m}\right\|=0$, so there is a sequence $x_{m}^{\prime} \in Y$ with $\lim \left\|x_{m}-x_{m}^{\prime}\right\|=0$ and so, by (5), (6) $\lim 2\left(\|x\|^{2}+\left\|x_{m}^{\prime}\right\|^{2}\right)-$ $\left\|x+x_{m}^{\prime}\right\|^{2}=0$ and therefore by LUR of $\|\cdot\|$ on $Y, \lim \left\|x-x_{m}^{\prime}\right\|=0$ and thus $\lim \left\|x-x_{m}\right\|=0$, a contradiction with (2).

If $x \notin Y$, write $x=y_{0}+a_{0}, a_{0}=S \hat{x}, y_{0} \in Y$. From LUR of $\|\cdot\|$ on $Y$, there is $\delta \in(0,1 / 2)$ such that whenever

$$
\begin{aligned}
y \in Y,\left\|y-y_{0}\right\| & \leqq \delta, z \in Y, \text { and } 2\left(\|y\|^{2}+\|z\|^{2}\right)-\|y+z\|^{2} \\
& \leqq \delta,
\end{aligned}
$$

then, $\|y-z\| \leqq \varepsilon / 2$. By (3) and LUR of $\|\hat{\bullet}\|$,

$$
\lim \left\|\widehat{x}_{n}-\hat{x}\right\|=0
$$

and thus,

$$
\lim S \widehat{x}_{m}=S \widehat{x}=a_{0}
$$

Let

$$
\left.\widehat{a}_{n} \in\left\{\hat{a}_{n}\right\}, \lim \hat{a}_{n}=\hat{a}_{0}=\hat{x} \text { (and thus } \lim a_{n}=a_{0}\right) .
$$

Furthermore,

$$
\lim \left\|P_{n}\right\|=\left\|a_{0}\right\| \cdot\left\|\hat{a}_{0}\right\|^{-1} .
$$

Let $\delta_{1}=\min \left\{\left[1+\left(5\left(\left\|a_{0}\right\| \cdot\left\|\hat{a}_{0}\right\|^{-1}+2\right)\right)^{2}(K+1)\right]^{-1} \delta, \varepsilon / 8\right\}(\delta$ from $(7))$. Choose $n_{0} \in N$ so that

(a) $\left\|P_{n_{0}}\right\| \leqq\left\|a_{0}\right\| \cdot\left\|\hat{a}_{0}\right\|^{-1}+1$ 
(b) $\left\|a_{n}-a_{0}\right\|<\delta_{1}$ for each $n \geqq n_{0}$

(c) $\left\|\hat{x}_{m}-\hat{x}\right\|<\delta_{1}$ for each $m \geqq n_{0}$.

Keeping this $n_{0}$ fixed, choose $n_{1} \geqq n_{0}$ so that

(d) $2\left(\left\|P_{n_{0}}^{\prime}(x)\right\|^{2}+\left\|P_{n_{0}}^{\prime}\left(x_{m}\right)\right\|^{2}\right)-\left\|P_{n_{0}}^{\prime}\left(x+x_{m}\right)\right\|^{2}<\delta_{1}$ for each $m \geqq n_{1}$. Choose $z_{n_{0}} \in \widehat{a}_{n_{0}}$ such that

$$
\left\|z_{n_{0}}-x\right\|<\delta_{1}
$$

and $x_{n_{0}}^{\prime} \in \widehat{a}_{n_{0}}$ such that

$$
\left\|x_{n_{0}}^{\prime}-x_{n_{1}}\right\|<2 \delta_{1} .
$$

Since $x_{n_{0}}^{\prime}=a_{n_{0}}+u_{n_{0}}, z_{n_{0}}=a_{n_{0}}+v_{n_{0}}$ for some $u_{n_{0}}, v_{n_{0}} \in Y$,

$$
P_{n_{0}}^{\prime}\left(x_{n_{0}}^{\prime}\right)=x_{n_{0}}^{\prime}-P_{n_{0}}\left(x_{n_{0}}^{\prime}\right)=u_{n_{0}} \in Y \text { and } P_{n_{0}}^{\prime}\left(z_{n_{0}}\right)=v_{n_{0}} \in Y \text {. }
$$

Furthermore, by (d), (a), (12), (13),

$$
\begin{aligned}
2\left(\left\|P_{n_{0}}^{\prime}\left(z_{n_{0}}\right)\right\|^{2}\right. & \left.+\left\|P_{n_{0}}^{\prime}\left(x_{n_{0}}^{\prime}\right)\right\|^{2}\right)-\left\|P_{n_{0}}^{\prime}\left(z_{n_{0}}+x_{n_{0}}^{\prime}\right)\right\|^{2} \leqq 2\left(\left\|P_{n_{0}}^{\prime}(x)\right\|^{2}+\left\|P_{n_{0}}^{\prime}\left(x_{n_{1}}\right)\right\|^{2}\right. \\
& -P_{n_{0}}^{\prime}\left\|\left(x+x_{n_{1}}\right)\right\|^{2}+2\left\|P_{n_{0}}^{\prime}\left(z_{n_{0}}-x\right)\right\|\left(\left\|P_{n_{0}}^{\prime}\left(z_{n_{0}}\right)\right\|+\left\|P_{n_{0}}^{\prime}(x)\right\|\right) \\
& +2\left\|P_{n_{0}}^{\prime}\left(x_{n_{0}}^{\prime}-x_{n_{1}}\right)\right\|\left(\left\|P_{n_{0}}^{\prime}\left(x_{n_{0}}^{\prime}\right)\right\|+\left\|P_{n_{0}}^{\prime}\left(x_{n_{1}}\right)\right\|\right) \\
& +\left(\left\|P_{n_{0}}^{\prime}\left(z_{n_{0}}-x\right)\right\|+\left\|P_{n_{0}}^{\prime}\left(x_{n_{0}}^{\prime}-x_{n_{1}}\right)\right\|\right) \\
& \times\left(\left\|P_{n_{0}}^{\prime}\left(z_{n_{0}}\right)\right\|+\left\|P_{n_{0}}^{\prime}(x)\right\|+\left\|P_{n_{0}}^{\prime}\left(x_{n_{0}}^{\prime}\right)\right\|+\left\|P_{n_{0}}^{\prime}\left(x_{n_{1}}\right)\right\|\right) \\
\leqq & \delta_{1}\left(1+\left(5\left(\left\|\alpha_{0}\right\| \cdot\left\|\hat{a}_{0}\right\|^{-1}+2\right)\right)^{2}(K+1)\right) \leqq \delta .
\end{aligned}
$$

Thus, by (7) and (14),

$$
\varepsilon / 2 \geqq\left\|P_{n_{0}}^{\prime}\left(x_{n_{0}}^{\prime}\right)-P_{n_{0}}^{\prime}\left(z_{n_{0}}\right)\right\|=\left\|x_{n_{0}}^{\prime}-z_{n_{0}}\right\| \text {. }
$$

So, $\left\|x_{n_{1}}-x\right\| \leqq\left\|x_{n_{0}}^{\prime}-z_{n_{0}}\right\|+\left\|x_{n_{1}}-x_{n_{0}}^{\prime}\right\|+\left\|z_{n_{0}}-x\right\| \leqq(7 / 8) \varepsilon<\varepsilon$, a contradiction.

For the case of rotund norms we define the norm |||||| by the same formula as above.

Again, suppose

$$
2\left(\left.\|x\|\right|^{2}+\||| y\|^{2}\right)-\|x+y\|^{2}=0
$$

and

$$
\|x-y\|>\varepsilon>0
$$

From (1'),

$$
\begin{gathered}
2\left(\|\hat{x}\|^{2}+\|\hat{y}\|^{2}\right)-\|\hat{x}+\hat{y}\|^{2}=0 \\
2\left(\left\|P_{n}^{\prime}(x)\right\|^{2}+\|\left. P_{n}^{\prime}(y)\right|^{2}\right)-\left\|P_{n}^{\prime}(x+y)\right\|^{2}=0 \quad \text { for } \quad n \in N \\
\left.2\left(\|x\|^{2}+\|y\|^{2}\right)-\|x+y\|^{2}\right)=0 .
\end{gathered}
$$


If $x \in Y, \widehat{x}=0$ and from $\left(3^{\prime}\right), \hat{y}=0$, so $y \in Y$ and from $R$ of $\|\cdot\|$ on $Y$ and $\left(5^{\prime}\right), x=y$.

If $x \notin Y$, then by $R$ of $|\hat{\bullet}|$ and by $\left(3^{\prime}\right), \hat{x}=\hat{y}$. So, write $x=$ $a_{0}+y_{0}, y=a_{0}+z_{0}, y_{0}, z_{0} \in Y, a_{0}=S \hat{x}$. By $R$ of $\|\cdot\|$ on $Y$, there is a $(1 / 2)>\delta>0$ such that whenever

$$
\begin{aligned}
& y \in Y, \quad z \in Y, \quad\left\|y-y_{0}\right\| \leqq \delta, \quad\left\|z-z_{0}\right\| \leqq \delta, \\
& 2\left(\|y\|^{2}+\|z\|^{2}\right)-\|y+z\|^{2} \leqq \delta,
\end{aligned}
$$

then

$$
\|y-z\| \leqq \varepsilon / 2 \text {. }
$$

Denote by $\delta_{1}=\min \left\{\left[1+\left(5\left(\left\|a_{0}\right\| \cdot\left\|\hat{a}_{0}\right\|^{-1}+2\right)\right)^{2}(K+1)\right]^{-1} \delta, \varepsilon / 8\right\}$, where $K=\max (\|x\|=\|y\|, 1)$. Let $\hat{a}_{n} \in\left\{\hat{a}_{n}\right\}, \lim \hat{a}_{n}=\hat{a}_{0}=\hat{x}, a_{n}=S \hat{a}_{n}$. Then $\lim a_{n}=a_{0}, \lim \left\|P_{n}\right\|=\left\|a_{0}\right\| \cdot\left\|\hat{a}_{0}\right\|^{-1}$.

Thus we can choose $n_{0} \in N$ so that $\left\|P_{n_{0}}\right\| \leqq\left\|a_{0}\right\| \cdot\left\|\hat{a}_{0}\right\|^{-1}+1$, $\left\|a_{n_{0}}-a_{0}\right\|<\delta_{1}$. Choose $y_{n_{0}}, z_{n_{0}} \in \hat{a}_{n_{0}}$ such that $\left\|z_{n_{0}}-x\right\|<\delta_{1},\left\|y_{n_{0}}-y\right\|<$ $\delta_{1}$. Since

$$
\begin{aligned}
y_{n_{0}} & =a_{n_{0}}+z_{n_{0}}, z_{n_{0}}=a_{n_{0}}+v_{n_{0}}, u_{n_{0}}, v_{n_{0}} \in Y, P_{n_{0}}^{\prime}\left(y_{n_{0}}\right) \\
& =y_{n_{0}}-P_{n_{0}}\left(y_{n_{0}}\right)=u_{n_{0}} \in Y .
\end{aligned}
$$

Furthermore,

$$
\begin{aligned}
2\left(\left\|P_{n_{0}}^{\prime}\left(z_{n_{0}}\right)\right\|^{2}\right. & \left.+\left\|P_{n_{0}}^{\prime}\left(y_{n_{0}}\right)\right\|^{2}\right)-\left\|P_{n_{0}}^{\prime}\left(y_{n_{0}}+z_{n_{0}}\right)\right\|^{2} \leqq 2\left(\left\|P_{n_{0}}^{\prime} x\right\|^{2}\right. \\
& \left.+\left\|P_{n_{0}}(y)\right\|^{2}\right)-\left\|P_{n_{0}}(x+y)\right\|^{2} \\
& +2 \cdot\left\|P_{n_{0}}^{\prime}\left(z_{n_{0}}-x\right)\right\|\left(\left\|P_{n_{0}}^{\prime}\left(z_{n_{0}}\right)\right\|+\left\|P_{n_{0}}^{\prime}(x)\right\|\right) \\
& +2\left\|P_{n_{0}}^{\prime}\left(y_{n_{0}}-y\right)\right\| \cdot\left(\left\|P_{n_{0}}^{\prime}\left(y_{n_{0}}\right)\right\|+\left\|P_{n_{0}}^{\prime}(y)\right\|\right) \\
& +\left(\left\|P_{n_{0}}^{\prime}\left(y_{n_{0}}-y\right)\right\|+\left\|P_{n_{0}}^{\prime}\left(z_{n_{0}}-x\right)\right\|\right) \\
& \times\left(\left\|P_{n_{0}}^{\prime}\right\| \cdot\left[\left\|y_{n_{0}}\right\|+\left\|z_{n_{0}}\right\|+\|x\|+\|y\|\right]\right) \\
\leqq & \delta_{1}\left(1+\left(5\left(\left\|a_{0}\right\| \cdot\left\|a_{0}\right\|^{-1}+2\right)\right)^{2}(K+1)\right) \leqq \delta
\end{aligned}
$$

Thus, by $\left(6^{\prime}\right),\left(7^{\prime}\right), \varepsilon / 2 \geqq\left\|P_{n_{0}}^{\prime}\left(y_{n_{0}}\right)-P_{n_{0}}^{\prime}-\left(z_{n_{0}}\right)\right\|=\left\|y_{n_{0}}-z_{n_{0}}\right\|$. So, $\|x-y\| \leqq\left\|x-z_{n_{0}}\right\|+\left\|y_{n_{0}}-z_{n_{0}}\right\|+\left\|y_{n_{0}}+y\right\| \leqq(3 / 4) \varepsilon<\varepsilon$, a contradiction.

We finish the note with the following

Question. Can Theorem 1 be generalized for the case of weakly compactly generated $X / Y$ ? 


\section{REFERENCES}

1. J. Diestel, Geometry of Banach spaces, Selected topics, Lecture Notes in Math. 485, Springer-Verlag, 1975.

2. K. John and V. Zizler, On extension of rotund norms, Bull. Acad. Polon. Sci. Sér. Sci. Math. Astronom. Phys., 24 (1976), 705-707.

3. M. I. Kadec, Spaces isomorphic to a locally uniformly convex space, Izv. vysch. Ucheb. Zaved. Matematika, 6 (1959), 51-57 and 6 (1961), 86-87.

4. J. Lindenstrauss and L. Tzafriri, Classical Banach spaces, Lecture Notes in Math. 338, Springer-Verlag, 1973.

Received May 16, 1978.

Mathematical Institute, Czechoslovak Academy of Sciences

Žitná 25, Prague

AND

ChaRles University

SOKOLOVSKÁ 83

Prague, Czechoslovakia 



\section{PACIFIC JOURNAL OF MATHEMATICS}

\section{EDITORS}

Donald BABBITT (Managing Editor)

University of California

Los Angeles, CA 90024

HUGo RossI

University of Utah

Salt Lake City, UT 84112

C. C. MOORE and ANDREW OGG

University of California

Berkeley, CA 94720

\section{J. DuGUNDJI}

Department of Mathematics

University of Southern California

Los Angeles, CA 90007

R. FINN and J. Milgram

Stanford University

Stanford, CA 94305

ASSOCIATE EDITORS
E. F. BECKENBACH
B. H. NeumanN
F. WOLF
K. YoSHIDA

\section{SUPPORTING INSTITUTIONS}

\author{
UNIVERSITY OF BRITISH COLUMBIA \\ CALIFORNIA INSTITUTE OF TECHNOLOGY \\ UNIVERSITY OF CALIFORNIA \\ MONTANA STATE UNIVERSITY \\ UNIVERSITY OF NEVADA, RENO \\ NEW MEXICO STATE UNIVERSITY \\ OREGON STATE UNIVERSITY \\ UNIVERSITY OF OREGON
}

\author{
UNIVERSITY OF SOUTHERN CALIFORNIA \\ STANFORD UNIVERSITY \\ UNIVERSITY OF HAWAII \\ UNIVERSITY OF TOKYO \\ UNIVERSITY OF UTAH \\ WASHINGTON STATE UNIVERSITY \\ UNIVERSITY OF WASHINGTON
}

The Supporting Institutions listed above contribute to the cost of publication of this Journal, but they are not owners or publishers and have no responsibility for its content or policies.

Mathematical papers intended for publication in the Pacific Journal of Mathematics should be in typed form or offset-reproduced, (not dittoed), double spaced with large margins. Please do not use built up fractions in the text of the manuscript. However, you may use them in the displayed equations. Underline Greek letters in red, German in green, and script in blue. The first paragraph or two must be capable of being used separately as a synopsis of the entire paper. Please propose a heading for the odd numbered pages of less than 35 characters. Manuscripts, in triplicate, may be sent to any one of the editors. Please classify according to the scheme of Math. Reviews, Index to Vol. 39. Supply name and address of author to whom proofs should be sent. All other communications should be addressed to the managing editor, or Elaine Barth, University of California, Los Angeles, California, 90024.

50 reprints to each author are provided free for each article, only if page charges have been substantially paid. Additional copies may be obtained at cost in multiples of 50 .

The Pacific Journal of Mathematics is issued monthly as of January 1966. Regular subscription rate: $\$ 84.00$ a year (6 Vols., 12 issues). Special rate: $\$ 42.00$ a year to individual members of supporting institutions.

Subscriptions, orders for numbers issued in the last three calendar years, and changes of address should be sent to Pacific Journal of Mathematics, P.O. Box 969, Carmel Valley, CA 93924, U.S.A. Older back numbers obtainable from Kraus Periodicals Co., Route 100, Millwood, NY 10546.

PUBLISHED BY PACIFIC JOURNAL OF MATHEMATICS, A NON-PROFIT CORPORATION

Printed at Kokusai Bunken Insatsusha (International Academic Printing Co., Ltd.). 8-8, 3-chome, Takadanobaba, Shinjuku-ku, Tokyo 160, Japan.

Copyright (C) 1979 by Pacific Journal of Mathematics Manufactured and first issued in Japan 


\section{Pacific Journal of Mathematics}

\section{Vol. 82 , No. 2 \\ February, 1979}

Krishnaswami Alladi and Paul Erdős, On the asymptotic behavior of large prime

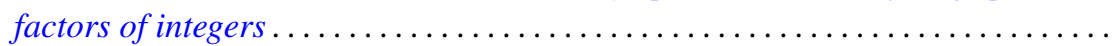

Alfred David Andrew, A remark on generalized Haar systems in $L_{p}$,

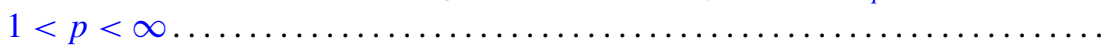

John M. Baker, A note on compact operators which attain their norm . . ........

Jonathan Borwein, Weak local supportability and applications to

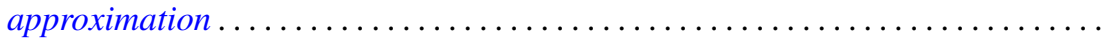

Tae Ho Choe and Young Soo Park, Wallman's type order compactification ........

Susanne Dierolf and Ulrich Schwanengel, Examples of locally compact

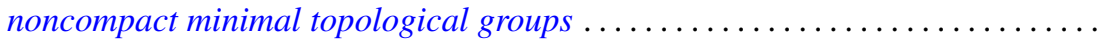

Michael Freedman, A converse to (Milnor-Kervaire theorem) $\times R$ etc. . . . . . . .

George Golightly, Graph-dense linear transformations ..................

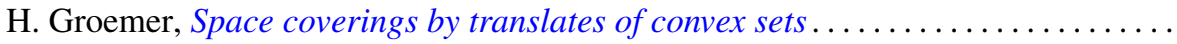

Rolf Wim Henrichs, Weak Frobenius reciprocity and compactness conditions in

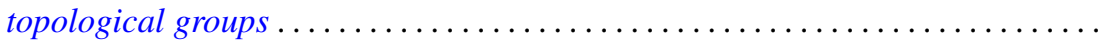

Horst Herrlich and George Edison Strecker, Semi-universal maps and universal

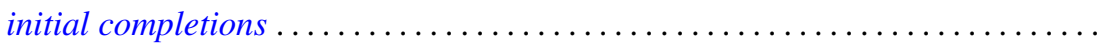

Sigmund Nyrop Hudson, On the topology and geometry of arcwise connected,

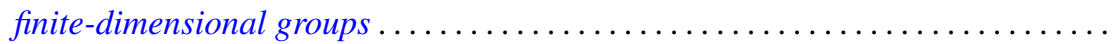

K. John and Václav E. Zizler, On extension of rotund norms. II .............

Russell Allan Johnson, Existence of a strong lifting commuting group of transformations. II.

Bjarni Jónsson and Ivan Rival, Lattice varieties covering the smallest nonmodular variety

Grigori Abramovich Kolesnik, On the order of Dirichlet L-functions .

Robert Allen Liebler and Jay Edward Yellen, In search of nonsolvable groups of

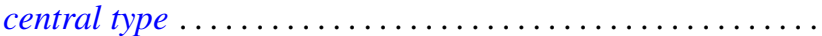

Wilfrido Martínez T. and Adalberto Garcia-Maynez Cervantes, Unicoherent plane Peano sets are $\sigma$-unicoherent ...

M. A. McKiernan, General Pexider equations. I. Existence of injective

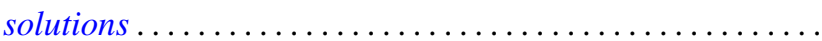

M. A. McKiernan, General Pexider equations. II. An application of the theory of webs.

Jan K. Pachl, Measures as functionals on uniformly continuous functions . .

Lee Albert Rubel, Convolution cut-down in some radical convolution algebras ...

Peter John Slater and William Yslas Vélez, Permutations of the positive integers

with restrictions on the sequence of differences. II . . .

Raymond Earl Smithson, A common fixed point theorem for nested spaces ....

Indulata Sukla, Generalization of a theorem of McFadden .... . . .

Jun-ichi Tanaka, A certain class of total variation measures of analytic measures.

Kalathoor Varadarajan, Modules with supplements .............. 